\title{
Review on Aluminium Silicon Carbide Metal Matrix Composite
}

\author{
Abhishek Singh \\ Assistant Professor, \\ Department of Mechanical \\ Engineering \\ Lok Nayak Jai Prakash Institute of \\ Technology Chapra, Bihar
}

\author{
Rahul Chaurasia \\ Assistant Professor, \\ Department of Mechanical \\ Engineering \\ Lok Nayak Jai Prakash Institute of \\ Technology Chapra, Bihar
}

\author{
Chandan Kumar \\ Assistant Professor, \\ Department of Mechanical \\ Engineering \\ Lok Nayak Jai Prakash Institute of \\ Technology Chapra, Bihar
}

\begin{abstract}
Good strength to weight ratio is always a interest of researchers to make the things more compact. Aluminium metal matrix composites are widely used in various industries ranging from house hold application to aerospace. Involvement of $\mathrm{SiC}$ in particulate form shows marginally increase in mechanical properties of Aluminium. Improvement in mechanical properties such as tensile strength, Hardness, toughness etc by varying the percent composition of $\mathrm{SiC}$ is being reviewed in this literature along with the fabrication techniques and effect of some alloying metals.
\end{abstract}

Keywords - Stirr casting, Metal matrix composite, Al-SiC, Mechanical Properties.

\section{INTRODUCTION}

Aluminium and its alloys have gained vast and huge industrial significance because of the exceptional combination of physical and mechanical properties over the base metal. These properties include: high strength, high abrasion and wear resistance, high stiffness, low thermal expansion, improved damping capacity etc. but, the modern development in field of material science and technology demands advanced engineering materials which are which are strong, light and less expensive, posses good strength to weight ratio, and which can also be used in various engineering applications, especially in field of transportation, aerospace and military engineering related areas [1,2].

Metal matrix composites (MMCs) are known to offer such tailored properties which are highly required in a wide range of engineering applications [3-5]. MMC is one marvelous example of an engineered combination of metal (usually the Matrix) and some hard particles (called Reinforcement) [6]. MMCs are the most promising materials in attaining enhanced mechanical properties such as: Hardness, ultimate tensile strength, Young's modulus, Yield strength, due to the presence of very fine (micro) sized reinforcement particles into the matrix $[7,8]$. MMC's also exhibit properties like: light weight, greater resistance to corrosion, oxidation and wear.

Huge leap in processing and enhancing properties of MMCs has been made on various composites in the past [9]. Metal matrix composites (MMCs), such as $\mathrm{SiCp}-\mathrm{Al}$ composites; have been attracting more and more interest because of their outstanding dimension stability, low expansion coefficient, as well as high specific strength and stiffness with lesser cost $[10,11]$. A number of materials are being used as reinforcements, such as $\mathrm{SiC}[12], \mathrm{Al}_{2} \mathrm{O}_{3}[13], \mathrm{B}_{4} \mathrm{C}[14,15]$, $\mathrm{TiB}_{2}$ [16-18], $\mathrm{ZrO}_{2}$ [19-21], $\mathrm{SiO}_{2}$ [22], TiC [23] and graphite to improve the properties of Aluminium alloys [24].

However, the crucial challenge which lies in field of processing of these engineering materials is to control its microstructure, mechanical properties and product cost through optimization of its chemical composition, the processing method and heat treatment procedures [25]. Non homogeneous distribution of the reinforcement is one of the biggest problems faced during casting of metal matrix composites [26]. The homogeneous distribution of reinforced particles in the matrix alloy is influenced by various factors like: method used for particle incorporation, rheological behaviour of the matrix melt, the, interaction between matrix and particles before, during, and after mixing [27].

Many processing techniques, including melt infiltration and semi-solid stirring have been suggested to fabricate $\mathrm{SiC}$ particles reinforced MMCs. But, due to simplicity in processing, flexibility and lesser cost, semi-solid stirring is considered as the best method amongst all these techniques [28]. Another problem of unwettability between the metal matrix and reinforcement of $\mathrm{SiCp}-\mathrm{Al}$ composites can be solved by using stirring technique, which also aids in enhancing the mechanical properties of the composites. During stir casting of $\mathrm{SiCp}-\mathrm{Al}$ composites, addition of magnesium $(\mathrm{Mg})$ into the aluminium melt improves the wettability of reinforcement with the matrix, by increasing the interface bonding strength and restraining the deleterious reactions at the interface [29-31].

The alloying elements, which are classified as major and minor elements and/or microstructure modifiers or impurities, can be selected on the basis of their effects and suitability [32]. For Aluminium and its alloys, major elements typically include Silicon $(\mathrm{Si})$, Magnesium $(\mathrm{Mg})$, and Copper $(\mathrm{Cu})$.

Silicon ( $\mathrm{Si}$ ): is mostly used single alloying element in majority of aluminium alloys. It is solely responsible for good castability, increase in overall strength, along with corrosion and wear resistance. Adding Si to aluminium also enhances the thermal dimensional stability, elastic modulus, and 
thermal conductivity of the composite, but decreases the machinablity consequently [33]. Depending on its concentration by weight (\%), It has been observed that with increase in $\mathrm{Si}$ content, ultimate tensile strength increases slightly (for $3-8 \% \mathrm{Si}$ ) with a linear increase later on (for 8$15 \% \mathrm{Si}$ ). It was also reported, that the hardness increases with increase in $\mathrm{Si}$ content $(12 \%)$ to $70 \mathrm{MPa}$, whereas it then decreases to $60 \mathrm{MPa}$ with a further addition $(15 \% \mathrm{Si})$ [34].

Magnesium (Mg): provides better work hardening characteristics and extremely high strength without any significant reduction in ductility of aluminium. It also imparts good weldability and corrosion resistance [35, 36]. Silicon combines with magnesium to form a hardening phase $\mathrm{Mg}_{2} \mathrm{Si}$ which provides the strengthening.

Combined Effect of $\mathrm{Si} \& \mathrm{Mg}$ : can help to improve the thermo-mechanical properties of the composite/alloy, especially the wettability. Shubin et al. [33], in their work observed good thermo-mechanical properties, for Si content lower than $12 \% \mathrm{wt}$ and for $\mathrm{Mg}$ content in the range of 4 $8 \%$ wt. However, a reduction in bending strength and thermal conductivity was significant for $\mathrm{Si}$ content rising beyond $12 \% \mathrm{wt}$, and higher levels of porosity was significant for $\mathrm{Mg}$ content beyond $8 \%$ wt.

Jamaluddin et al., concluded most of the literature available is based on composites such as: Al7075, Al6061, Al2214, A12618, A1359, and A1357 [37].

\section{PROCESSING TECHNIQUE OF METAL MATRIX COMPOSITES}

Processing technique is important factor. It must ensure uniform distribution of $\mathrm{SiC}$ particle throughout the matrix material. Mechanical Stirr casting is one of the processing techniques for preparation of $\mathrm{Al}-\mathrm{SiC}$ metal matrix Composites. However it has some constraint like wettability between two substances, porosity etc but it can produce wide range and also less expensive, without damage in reinforcement [38].Powder Metallurgy is also one of the processing technique that is used for Metal matrix Composites.[39]. Some researchers conclude that it is Expensive technique and there is chance of reinforcement fracture. Squeeze Casting is other technique for processing of matal matrix composites. It may cause damage to reinforcement materials [40]. Spray Casting [41] and electromagnetic Stirring [42] are also used for processing. Stirring time and Speed also influence the properties of Metal matrix Composites [43]. Prabhu et al. found better hardness on $600 \mathrm{rpm}$ at 10 min condition.

\section{MECHANICAL PROPERTIES}

TENSILE STRENGTH: Alaneme[44] et al. found the improved ultimate tensile strength from $112.93 \mathrm{MPa}$ to 158.5 $\mathrm{MPa}$ by increasing the $\mathrm{SiC}$ volume percentage from $0 \%$ to $12 \%$ respectively, Yield strength was found to be improved from $80.75 \mathrm{MPa}$ to $120.24 \mathrm{MPa}$ of as cast alloys.
Rahman et al.[46] also found significance improvement in tensile strength by increasing the wt\% of $\mathrm{SiC}$ in metal matrix Composite.

HARDNESS: Singla et al.[45] found improved in Hardness (BHN) from 28.5 to 45.5 when $\mathrm{SiC}$ was $0 \%$ and $25 \%$ respectively.

TOUGHNESS: Singla et al.[45] found increase in impact strength $12 \mathrm{Nm}$ to $34 \mathrm{Nm}$ when $\mathrm{SiC}$ is $0 \%$ and $25 \%$ respectively. At $25 \%$ he found maximum value and further increase in $\mathrm{SiC}$ decrease in impact strength was found.

WEAR: Rahman et al.[46] concluded the reduction in cumulative mass losses while increasing the fraction of $\mathrm{SiC}$ in composite.

\section{CONCLUSION}

In this paper advantages of Aluminium- SiC metal matrix Composites are discussed along with different processing technique. Effect of other metals like magnesium and silicon are also discussed Study shows that the influence of reinforcement as $\mathrm{SiC}$ in particulate form is capable to tailored the properties of Aluminium upto some extent. Study also shows that Stirr Casting technique is being widely used and preferred over other processes. However there is concern about the wettability of reinforcement around the matrix material. Porosity is also a problem in Stirr Casting technique. Reinforcing Aluminum and its alloys with ceramics particles has shown an appreciable increase in its mechanical properties.

\section{REFERENCES}

[1] Abedi, K., \& Emamy, M., "The effect of Fe, Mn and $\mathrm{Sr}$ on the microstructure and tensile properties of A356-10\% SiC composite", Materials Science and Engineering: A, 527 (16-17), pp.3733-3740, (2010).

[2] Dwivedi, S.P., Sharma, S., \& Mishra, R.K., "Microstructure and Mechanical Properties of A356/SiC Composites Fabricated by Electromagnetic Stir Casting", Procedia Materials Science, 6 , pp. $1524-1532$, (2014).

[3] Tjong, S. C., "Processing and deformation characteristics of metals reinforced with ceramic nano-particles", Nanocrystalline materials [Internet]. 2nd ed. Oxford: Elsevier; 2014. p. 269-304 [cited 2014 Aug 25], (2014).

[4] Rino, J. J., Chandramohan, D., Sucitharan, K. S., \& Jebin, V. D,”An overview on development of aluminium metal matrix composites with hybrid reinforcement", IJSR India, Online ISSN 2012:23197064, (2012)

[5] Bodunrin, M. O., Alaneme, K. K., \& Chown, L. H. "Aluminium matrix hybrid composites: A review of reinforcement philosophies; mechanical, corrosion and tribological characteristics", Journal of Materials Research and Technology, 4(4), pp.434-445, (2015).

[6] Meena, K. L., Manna, A., Banwait, S. S., \& Jaswanti. "An Analysis of Mechanical Properties of the Developed Al/SiC-MMC's", American Journal of Mechanical Engineering, 1(1), pp.14-19, (2013).

[7] Vencl, A. et al. "Structural, mechanical and tribological properties of A356 aluminium alloy reinforced with $\mathrm{Al}_{2} \mathrm{O}_{3}, \mathrm{SiC}$ and $\mathrm{SiC}+$ Graphite particles", Journal of Alloys Compd , 506:631-9, (2010).

[8] Yung, C. K., \& Chan, S. L. I. "Tensile Properties of Nanometric $\mathrm{Al}_{2} \mathrm{O}_{3}$ Particulate Reinforced Aluminium Matrix Composites", Journal of Materials Chemistry and Physics, 85, pp.438-443, (2004)

[9] Kaczmar, J. W., Pietrzak, K., \& Wlosinki, W. "The production and application of metal matrix composite materials", Journal of Material Processing and Technology, 106, pp.58-67, (2000).

[10] Taha, M. A.. "Practicalization of cast metal matrix composites MMCs", Journal of Material Design, 22, pp.431-441, (2002).

[11] Geng, L., Zhang, H. W., Li, H. Z., Guan, L. N., \& Huang, L. J "Effects of $\mathrm{Mg}$ content on microstructure and mechanical properties of $\mathrm{SiCp} / \mathrm{Al}-\mathrm{Mg}$ composites fabricated by semi-solid stirring 
technique", Transactions of Nonferrous Metals Society of China, 20, pp.1851-1855, (2010)

[12] Soltani, S., Khosroshahi, R. A., Mousavian, R. T., Jiang, Z. Y., Boostani, A. F., \& Brabazon, D. "Stir casting process for manufacture of $\mathrm{Al}-\mathrm{SiC}$ composites", RARE METALS, doi:10.1007/s12598-015-0565-7, (2015)

[13] Valibeygloo, N., Khosroshahi, R. A., \& Mousavian, R. T. "Microstructural and mechanical properties of $\mathrm{Al}-4.5 \mathrm{wt} \% \mathrm{Cu}$ reinforced with alumina nanoparticles by stir casting method", International Journal of Minerals, Metallurgy and Materials, 20(10), pp.978-985, (2013)

[14] Patil, K. L., Ali, M., \& Nagaral, M "Studies on Al8081-B 4 C Metal Matrix Composites Fabricated by Stir Casting Method", International Journal Of Modern Engineering Research, 4(7), pp.1-4, (2014).

[15] Canakci, A., Arslan, F., \& Varo, T "Physical and mechanical properties of stir-casting processed AA2024/B $\mathrm{B}_{4} \mathrm{Cp}$ composites", Science and Engineering of Composite Materials, 21(4), pp.505$515,(2014)$

[16] Suresh, S., \& Moorthi, N. S. V. "Aluminium-Titanium Diboride (Al$\mathrm{TiB}_{2}$ ) Metal Matrix Composites: Challenges \& Opportunities", Procedia Engineering, 38, pp.89 - 97, (2012).

[17] Sreenivasana, A., Vizhian, S. P., Shivakumar, N. D., Muniraju, M., \& Raguraman, M. "A study of microstructure and wear behaviour of $\mathrm{TiB}_{2} / \mathrm{Al}$ metal matrix composites", Latin American Journal of Solids and Structures, 8, pp.1-8, (2011)

[18] Poria, S., Sahoo, P., \& Sutradhar. "Tribological Characterization of Stir-cast Aluminium-TiB2 Metal Matrix Composites", Silicon, 8(4), pp.591-599, (2016)

[19] Hajizamani, M., \& Baharvandi, H. "Fabrication and Studying the Mechanical Properties of A356 Alloy Reinforced with $\mathrm{Al}_{2} \mathrm{O}_{3}-10 \%$ Vol. $\mathrm{ZrO}_{2}$ Nanoparticles through Stir Casting", Advances in Materials Physics and Chemistry, 1, pp.26-30. (2011).

[20] Hemanth, J. "Fracture behavior of cryogenically solidified aluminium alloy reinforced with $\mathrm{Nano}-\mathrm{ZrO}_{2}$ metal matrix composites (CNMMCs)", Journal of Chemical Engineering and Materials Science, 2(8), pp.110-121. (2011).

[21] Patoliya, D. M., \& Sharma, S "Preparation and Characterization of Zirconium Dioxide Reinforced Aluminium Metal Matrix Composites", International Journal of Innovative Research in Science, Engineering and Technology, 4(5), pp.3315-3321, (2015).

[22] Deshmukh, P., \& Pathak, S. "Influence of Varying $\mathrm{SiO} 2 \%$ on the Mechanical Properties of Al Based MMC", Transactions of the Indian Institute of Metals, 65(6), pp.741-745, (2012)

[23] Moses, J. J., \& Sekhar, S. J. "Investigation on the Tensile Strength and Microhardness of AA6061/TiC Composites by Stir Casting", Transactions of the Indian Institute of Metals, doi:10.1007/s12666016-0891-y, (2016)

[24] Bharath, V., Nagaral, M., Auradi, V., \& Kori, S. A. "Preperation of 6061Al-Al2O3 MMC's by Stir Casting and Evaluation of Mechanical and Wear Properties", Procedia Materials Science, 6, pp.1658-1667, (2014).

[25] Chen, R., \& Zhang, G. "Casting defects and properties of cast A356 aluminium alloy reinforced with $\mathrm{SiC}$ particles", Composites Science and Technology, 47 (1), pp.51-56, (1993).

[26] Nather, S., Brabazon, D. and Looney, L. "Simulation of the Stir Casting Process," Journal of Materials Processing Technology, 143144, pp.567-571, (2003)

[27] Hashim, J., Looney, L., \& Hashmi, M. S. J.. "Particle Distribution in Metal Matrix Composites", Journal of Materials Processing Technology: Part-I, 123, pp.251-257, (2002)

[28] Zhou, W., \& Xu, Z. M. "Casting of SiC reinforced metal matrix composites", Journal of Material Processing and Technology, 63, pp.358-363, (1997)

[29] Hashim, J., Looney, L., \& Hashmi, M. S. J "The enhancement of wettability of $\mathrm{SiC}$ particles in cast aluminium matrix composites", Journal of Material Processing and Technology, 119, pp.329-335, (2001).

[30] Mitra, R., Rao, C. V. S., Maitri, R., \& Chakraborty, M. "Stability and response to rolling of the interfaces in cast $\mathrm{Al}-\mathrm{SiCp}$ and $\mathrm{Al}-\mathrm{Mg}$ alloy-SiCp composites", Journal of Material Science and Engineering: A, 379, pp.391-400, (2004).

[31] Beffort, O., Long S. Y., Cayron, C., Kuebler, J., \& Buffat, P. A. "Alloying effects on microstructure and mechanical properties of high volume fraction SiC-particle reinforced Al-MMCs made by squeeze casting infiltration", Journal of Composite Science and Technology, 67, pp.737-745, (2007)

[32] Rana, R. S., Purohit, R., \& Das, S. "Reviews on the Influences of Alloying elements on the Microstructure and Mechanical Properties of Aluminium Alloys and Aluminium Alloy Composites", International Journal of Scientific Research and Research Publications, 2(6), pp.1-7, (2012)

[33] Ren, S., He, X., Qu, X., Humail, I. S., \& Li, Y. "Effect of Mg and Si in the aluminium on the thermo-mechanical properties of pressure less infiltrated SiCp/Al Composites", Science and Technology, 67, pp.2103-2113, (2007).

[34] Abdel-Jaber, I. G. T., Omran, A. M., Khalil, K. A., Fujii, M., Seki, M., \& Yoshida, A“An Investigation into Solidification an Mechanical Properties behaviour of Al-Si Casting Alloys", International Journal of Mechanical \& Mechatronics Engineering, 10(4), pp.30-35, (2010)

[35] Davis, J. R "Corrosion of Aluminum and Aluminum alloys", ASM International, Ohio, (1999).

[36] Mondolfo, L. F. "Aluminum alloys: Structure and Properties", London, Butterworths. (1976).

[37] Hindi, J., Kini, U. A., Sharma, S. S., Gurumurthy, B. M., \& Shankar, M. C. G. "Mechanical Characterization of Stir Cast Al 6063 Matrix $\mathrm{SiC}$ Reinforced Metal Matrix Composites", $5^{\text {th }}$ International Conference on Automotive, Mechanical and Materials Engineering, Bali (Indonesia), pp.69-73. (2015),

[38] J. Hashim, L. Looney "Metal matrix composites: production by the stir casting method ", Journal of Materials Processing Technology 92-93, (1999).

[39] S.F. Moustafa, Z. Abdel-Hamid , A.M. Abd-Elhay Copper matrix $\mathrm{SiC}$ and $\mathrm{Al} 2 \mathrm{O} 3$ particulate composites by powder metallurgy technique, Materials Letters 53 (2002) $244-249$

[40] Adem Onat, Hatem akbulut, Fevzi Yilmaz “ Production and characterisation of silicon carbide particulate reinforced aluminiumcopper alloy matrix composites by direct squeeze casting method" Journal of Alloys and Compounds Volume 436, Issues 1-2, 14 June 2007, Pages 375-382.

[41] C.L. Buhrmaster, D.E. Clark, H.B. Smartt, "Spray Casting Aluminum and $\mathrm{Al} / \mathrm{SiC}$ Composites" November 1988, Volume 40, Issue 11, pp 44-45 The Journal of The Minerals, Metals \& Materials Society (TMS)

[42] Abhishek Kumar, Shyam Lal, Sudhir Kumar "Fabrication and characterization of $\mathrm{A} 359 / \mathrm{Al}_{2} \mathrm{O}_{3}$ metal matrix composite using electromagnetic stir casting method" Journal of Material research and technology "Volume 2, Issue 3, July-September 2013, Pages 250-254.

[43] S. Balasivanandha Prabu, L. Karunamoorthy, S. Kathiresan, B. Mohan"Influence of stirring speed and stirring time on distribution of particles in cast metal matrix composite" Journal of Materials Processing Technology 171 (2006) 268-273.

[44] K.K. Alaneme, A.O. Aluko "Fracture toughness (K1C) and tensile properties of as-cast and age-hardened aluminium (6063)-silicon carbide particulate composites" Scientia Iranica Volume 19, Issue 4, August 2012, Pages 992-996

[45] Manoj Singla, D. Deepak Dwivedi, Lakhvir Singh, Vikas Chawla "Development of Aluminium Based Silicon Carbide Particulate Metal Matrix Composite" Journal of Minerals \& Materials Characterization \& Engineering, Vol. 8, No.6, pp 455-467, 2009.

[46] Md. Habibur R. H.M. Mamum al R. "Characterization of Silicon Carbide Reinforced Aluminum Matrix Composites", Procedia Engineering Volume 90, 2014,pp 103-109. 